\title{
Retrospective Evaluation of Patients with Systemic Autoimmune Diseases Admitted to Intensive Care
}

\author{
Yoğun Bakıma Yatan Sistemik Otoimmün Hastalkları olan Hastaların Geriye Dönük İncelenmesi
}

${ }^{1}$ Ebru Karakoc, ${ }^{2}$ Ilkay Ceylan, ${ }^{3}$ Meryem Onay, ${ }^{3}$ Birgul Buyukkidan Yelken

${ }^{1}$ Cankiri State Hospital, Department of Anesthesia, Cankiri, Turkey

${ }^{2}$ SBU Bursa Yüksek Ihtisas Training and Research Hospital, Department of Anesthesiology and Reanimation, Bursa, Turkey

${ }^{3}$ Eskisehir Osmangazi University Faculty of Medicine, Department of Anesthesiology and Reanimation, Eskisehir, Turkey
Correspondence:

İlkay CEYLAN

Eskisehir Osmangazi University

Faculty of Medicine, Department of Anesthesiology and Reanimation, Eskisehir, Turkey e-mail: ceylanilkay@yahoo.com

\section{Abstract}

Systemic autoimmune diseases can cause life-threatening complications that require admission to the intensive care unit. Early recognition of these complications can improve patient outcomes. The aim of this study is to evaluate patients with systemic autoimmune diseases hospitalized in the intensive care unit and identify the factors affecting the patient outcomes. Patients (aged $>18$ ) with systemic autoimmune diseases who were hospitalized in a tertiary general intensive care unit between 2010 and 2020 were retrospectively analyzed. Demographic data, Acute Physiology and Chronic Health Evaluation (APACHE) II and Sequential Organ Failure Assessment (SOFA) scores, reasons for admission to the intensive care unit, information on treatments for primary diseases and those administered in the intensive care unit, and survival rates were recorded. The study included 67 adult patients. The main reason for hospitalization was infection $(n=35)$, and 43 patients died in the intensive care unit. The need for mechanical ventilation during intensive care hospitalization and the presence of fungal infection as per fungal cultures performed at hospitalization were found to be associated with mortality. In addition, the presence of high disease severity scores was associated with mortality. The mortality rate of patients with systemic autoimmune diseases requiring intensive care unit admission was found to be high. The majority of deaths occurred as a result of infections associated with immunosuppression. Such deaths can be prevented by implementing specific measures and conducting training targeting these issues.

Keywords: Vasculitis, mortality, intensive care unit, systemic autoimmune diseases

\section{Özet}

Sistemik otoimmün hastalıklar, yoğun bakım ünitesine kabul gerektiren hayatı tehdit eden komplikasyonlara neden olabilir. Bu komplikayonların erken tanınması hasta sonuçlarını iyileștirebilir. Bu çalışmanın amacı yoğun bakım ünitesine yatan sistemik otoimmün hastalığılan hastaları değerlendirimek ve sonuçlara etki eden faktörleri belirlemektir. Yöntem: 2010-2020 ylları arasında 3 basamak genel yoğun bakıma yatırılan sistemik otoimmün hastalıkları olan 18 yaş üstü hastalar geriye dönük olarak incelendi. Demografik bilgileri, APACHE 2 ve SOFA skorları, yoğun bakıma yatış nedenleri, primer hastalıklarına yönelik aldıkları tedaviler, yoğun bakımda uygulanan tedaviler ve sağ kalım oranları kayıt edildi. 67 erişkin hasta çalışmaya dahil edildi. Başlıca yatı̧ nedenlerinin enfeksiyon (n:35), olduğu görüldü. 43 hasta yoğun bakımda kaybedildi. Yoğun bakım yatıșı sırasında mekanik ventilasyon ihtiyacı olması ve yatış kültürlerinde mantar üremesi olması mortalite ile ilişkilii bulunmuştur. Ek olarak yüksek hastalık skorlarınn varlığı mortalite ile ilişkilli bulunmuştur.

Yoğun bakım ünitesine yatış gerektiren sistemik otoimmün hastalıkların ölüm oranı yüksektir. Ölümlerin büyük çoğunluğu immünsüpresyona bağlı enfeksiyon nedeniyle olmaktadır. Bu yönde uygulanacak tedbirler ve eğitimler ile bu ölümlerin önüne geçilebilir.

Anahtar Kelimeler: Vaskülit, mortalite, yoğun bakım ünitesi, sistemik otoimmün hastalıklar 


\section{Introduction}

Systemic autoimmune diseases (SADs) are diseases characterized by systemic inflammation caused by the dysfunction of immune system regulatory mechanisms and can affect any organ. They are classified as major rheumatological diseases and systemic vasculitis(1). The use of corticosteroids in the $1950 \mathrm{~s}$ and the introduction of immunosuppressants for treatment in the 1970s significantly increased the survival of patients with SADs. Nevertheless, SADs are associated with life-threatening complications that require intensive care unit (ICU) admission. The complications associated with organ failure are mainly related to disease activation or infections that develop after immunosuppressive therapy

Developments in diagnosis and treatment options for SADs also positively affect patient outcomes in ICU. Therefore, in our study, we aimed to examine patients with SADs hospitalized in our ICU and identify the factors affecting mortality in these patients.

\section{Methods}

This retrospective study included patients with SADs (age >18) who were treated in Eskişehir Osmangazi University Medical Faculty, Department of Anesthesiology and Reanimation Anesthesiology and Reanimation ICU between January 1, 2010 and January 1, 2020 and admitted to the ICU for $>24$ hours. Patients' data were collected from the hospital information management system and archived records. Ethics committee approval (Eskişehir Osmangazi University Ethical Committee; E25403353-050.99-133102, 13.01.2021) was obtained before starting the study. As the study was retrospective, informed consent was not sought from the patients.

The patients were divided into systemic connective tissue disease and systemic vasculitis groups. Age, gender, immunosuppressive therapy data, and reasons for ICU admission were recorded. Disease severity was assessed using the Acute Physiology and Chronic Health Evaluation (APACHE) II and Sequential Organ Failure Assessment (SOFA) scores. The need for invasive mechanical ventilation (IMV) or non-invasive mechanical ventilation (NIMV), renal replacement/dialysis therapy, plasmapheresis therapy, vasoactive drugs, and extracorporeal membrane oxygenation during ICU admission were recorded. Furthermore, the length of stay in the ICU and the outcome which led to discharge from the ICU were recorded. Patients were classified according to survival, and predictive factors for survival were identified.

\section{Statistical analysis}

All the data were analyzed using the Statistical Package for Social Sciences for Windows 22 on the computer. Descriptive values for quantitative (numerical) variables were expressed as mean \pm standard deviation, and those for qualitative (categorical) variables were expressed as frequency and percentage. The conformity of quantitative variables to a normal distribution was evaluated using the Shapiro-Wilk test. The relationship between qualitative variables was analyzed using the chi-square and Fisher's exact tests. Values with $\mathrm{p}<0.05$ were considered statistically significant.

\section{Results}

Patient records were analyzed, and 68 patients who met the criteria were included. One patient was excluded from the study due to the lack of data. Finally, a total of 67 patients, 42 females and 25 males, were included in the study. High APACHE II (23 \pm 8.22$)$ and SOFA (9.96 \pm 4.39$)$ scores indicated a high disease severity in the patients, and there was a statistically significant difference between the patients who survived and those who died $(\mathrm{p}<0.05)$.

The main category of diseases were systemic connective tissue diseases $(n=42)$ and systemic vasculitis $(n=25)$. Reasons for admission to the ICU were infection $(\mathrm{n}=35)$, active disease/exacerbation $(\mathrm{n}=24)$, and other $(\mathrm{n}=8)$. Pneumonia $(\mathrm{n}=26)$ was the leading cause of infectius cause of ICU admission. Pulmonary hemorrhage $(\mathrm{n}=11)$ was the leading cause of disease activation. The following types of vasculitis were identified: granulomatosis with polyangiitis (Wegener's granulomatosis) $(n=10)$, polyarteritis nodosa 
$(\mathrm{n}=6)$, Takayasu arteritis $(\mathrm{n}=1)$, eosinophilic granulomatosis with polyangiitis (Churge-Strauss syndrome $)(\mathrm{n}=1)$, microscopic polyangiitis $(n=3)$ and Behcet's disease $(\mathrm{n}=4)$. Rheumatic disease types were - systemic lupus erythematosus (SLE) (n $=19)$, ankylosing spondylitis $(\mathrm{n}=1)$, rheumatoid arthritis $(\mathrm{RA})(\mathrm{n}=12)$, sarcoidosis $(\mathrm{n}=4)$, Sjogren's disease $(\mathrm{n}=5)$, and scleroderma $(\mathrm{n}=1)$.

The mean length of stay in the ICU was $22.11 \pm 32.5$ days, and 43 patients $(64.17 \%)$ died during their ICU stay. The causes of death were sepsis $(\mathrm{n}=31)$, refractory hypoxemia $(\mathrm{n}=3)$, subarachnoid hemorrhage $(n=3)$, and disease exacerbation $(n=6)$.

Fifty-two patients had a diagnosis of SAD at the time of their admission to the ICU, and 16 patients were treated with corticosteroid therapy alone and 9 patients with only biological agents. Furthermore, 14 patients were diagnosed with SAD after hospitalization, and 1 patient was diagnosed after admission to the ICU.

During their stay in the ICU, the patients received corticosteroid $(\mathrm{n}=49)$, plasmapheresis therapy $(\mathrm{n}=11)$, and intravenous immunoglobulin $(\mathrm{n}=1)$ treatments for their primary disease. Fiftyseven patients received IMV and 10 patients received NIMV support. In addition, 33 patients required renal replacement therapy.

It was found that the need for IMV during hospitalization and presence of fungal infection according to cultures performed at the time of hospitalization were associated with mortality (Table 1).

Table 1. Factors affecting mortality

\begin{tabular}{|c|c|c|c|c|c|}
\hline & & \multicolumn{2}{|l|}{ Mortality } & \multirow[t]{2}{*}{ Total } & \multirow[t]{2}{*}{$\mathbf{p}$} \\
\hline & & No & Yes & & \\
\hline \multirow[t]{2}{*}{ Diagnostic status } & New diagnosis & $6(50)$ & $6(50)$ & 12 & \multirow{2}{*}{$\begin{array}{l}* \mathrm{X}^{2}: 1.27 \\
p: 0.258\end{array}$} \\
\hline & Chronic disease & $18(32,7)$ & $37(67,3)$ & 55 & \\
\hline \multirow[t]{2}{*}{ Primary diagnosis } & SRD & $17(40,5)$ & $25(59,5)$ & 42 & \multirow{2}{*}{$\begin{array}{l}\mathrm{X}^{2}: 1.06 \\
p: 0.303\end{array}$} \\
\hline & Vasculitis & $7(28)$ & $18(72)$ & 25 & \\
\hline \multirow[t]{3}{*}{ Reason for admission } & Exacerbation & $11(44)$ & $14(56)$ & 25 & \multirow{3}{*}{$\begin{array}{l}\mathrm{X}^{2}: 1.84 \\
p: 0.397\end{array}$} \\
\hline & Infection & $11(34,4)$ & $21(65,6)$ & 32 & \\
\hline & Other & $2(20)$ & $8(80)$ & 10 & \\
\hline \multirow{4}{*}{$\begin{array}{l}\text { Growth observed in cultures } \\
\text { performed at admission }\end{array}$} & Fungal & $21(50)$ & $21(50)$ & 42 & \multirow{4}{*}{$\begin{array}{c}* \mathrm{X}^{2}: 9.6 \\
p: 0.027\end{array}$} \\
\hline & $\begin{array}{l}\text { Gram-negative } \\
\text { bacteria }\end{array}$ & $1(9,1)$ & $10(90,9)$ & 11 & \\
\hline & Gram-positive bacteria & $2(20)$ & $8(80)$ & 10 & \\
\hline & Atypical bacteria & $\mathbf{0}(\mathbf{0})$ & $4(100)$ & 3 & \\
\hline \multirow[t]{3}{*}{ Steroid therapy use } & Yes & $3(27,3)$ & $8(72,7)$ & 11 & \multirow{3}{*}{$\begin{array}{l}\mathrm{X}^{2}: 0,79 \\
p: 0.67\end{array}$} \\
\hline & No & $5(31,3)$ & $11(68,8)$ & 16 & \\
\hline & Pulse steroid & $16(40)$ & $24(60)$ & 40 & \\
\hline \multirow[t]{2}{*}{ Immunomodulator use } & Yes & $16(40)$ & $24(60)$ & 40 & \multirow{2}{*}{$\begin{array}{l}\mathrm{X}^{2}: 0.75 \\
p: 0.385\end{array}$} \\
\hline & No & $8(29,6)$ & $19(70,4)$ & 27 & \\
\hline \multirow[t]{2}{*}{ Biological agent use } & Yes & $21(36,2)$ & $37(63,8)$ & 58 & \multirow{2}{*}{$\begin{aligned} * \mathrm{X}^{2}: 0.02 \\
p: 0.87\end{aligned}$} \\
\hline & No & $3(33,3)$ & $6(66,7)$ & 9 & \\
\hline \multirow[t]{2}{*}{ IMV } & No & $17(29,8)$ & $40(70,2)$ & 57 & \multirow{2}{*}{$\begin{array}{l}\mathrm{X}^{2:} 5.97 \\
p: 0.01\end{array}$} \\
\hline & Yes & $7(70)$ & $3(30)$ & 10 & \\
\hline
\end{tabular}




\begin{tabular}{llllll}
\hline $\begin{array}{l}\text { Immunosuppression therapy } \\
\text { administration in the ICU }\end{array}$ & Yes & $4(22,2)$ & $14(77,8)$ & $\mathbf{1 8}$ & $\mathrm{X}^{2}: 1,98$ \\
\multirow{2}{*}{ RRT } & No & $20(40,8)$ & $29(59,2)$ & 49 & $p: 0,159$ \\
& Yes & $13(38,2)$ & $21(61,8)$ & $\mathbf{3 4}$ & $\mathrm{X}^{2}: 0,17$ \\
& No & $11(33,3)$ & $22(66,7)$ & 33 & $p: 0.67$ \\
Plasmapheresis & Yes & $20(35,7)$ & $36(64,3)$ & $\mathbf{5 6}$ & $X^{2}: 0.01$ \\
& No & $4(36,4)$ & $7(63,6)$ & 11 & $p: 0.967$
\end{tabular}

SRD: Systemic rheumotologial diseases; IMV: Invasive mechanical ventilation; ICU: Intensive care unit; RRT: Renal replacement therapy

\section{Discussion}

In our study in which we evaluated 67 patients with SADs who were admitted to the ICU, we found that the mortality rate of this patient group was $64.17 \%$ and the most common cause of mortality was sepsis. In various publications, ICU mortality rate of patients with SADs varies between $17 \%$ and $33 \%$ (3). Another study reported that the mortality rate of patients with SADs was $16 \%-20 \%$ in Colombia and the USA(4).

In general, patients with SADs requiring ICU admission can be grouped as having rheumatic diseases or systemic vasculitis. In a study conducted in the USA in 2020, it was found that the most frequent admission to the ICU was due to SADs such as SLE, RA, and systemic vasculitis, which was similar to our study results (5). Unlike these data, as per previous studies conducted in the $90 \mathrm{~s}$, the most common SADs requiring ICU admission were RA and systemic vasculitis. According to Parperis et al., the reason for these differences is the success achieved in the last 20 years with the use of biological agents in the treatment and control of RA, resulting in fewer hospitalizations (6). In our study, the majority of the patients in the rheumatic disease group had SLE and RA. Ina study by Haijnen et al., 86 patients admitted to the internal ICU during a 5-year period were evaluated, and the most common reason for hospitalization was identified to be systemic vasculitis, sarcoidosis, systemic sclerosis, and SLE (1); this difference may be due to the ethnic characteristics of the population of that region. In a study evaluating 51 patients with SADs admitted to the ICU, 23 patients were followed with a diagnosis of small vessel vasculitis, and this group was found to have higher APACHE II and SOFA scores and Simplified Acute Physiology Score (SAPS) II; a greater need for renal replacement, transfusion of blood products, and immunosuppressive therapy; and higher ICU mortality rates $(60.9 \%)$ compared to the group of patients with other ADs (35.3\%) (7). In our study, a total of 25 patients required ICU admission due to systemic vasculitis.

According to some studies, the most common reasons for hospitalization of patients with rheumatic diseases who required ICU admission were sepsis (31\%), followed by pneumonia $\quad(10 \%) \quad(8)$ Although hospitalizations due to infection have been reported with rates of up to $60 \%$ in the literature, some publications have reported higher rates for acute exacerbations than those of infections as reasons for ICU admission $(9,10)$. Our study is in line with the literature since the most common reason for ICU admission was infection-related causes followed by exacerbation of the primary disease. Pneumonia and urosepsis are the leading infectious causes of ICU admission. The fact that the infections were treated before the occurrence of sepsis may be because the majority of our patients were hospitalized due to pneumonia.

Assessments regarding ICU admission of patients with SADs have shown that a high APACHE II score, multiple organ failure, and advanced age are associated with mortality (5). In several studies, an APACHE II score of $>19$ and a mean APACHE II score of 25 were associated with mortality, and the mean APACHE II scores of survivors were found to be 10 and 14.8 (k1-8,23). In our study, we did 
not establish threshold APACHE II and SOFA scores for evaluating mortality, but we found that scores at hospitalization of patients who died were significantly higher than those of patients who survived. Polok et al. reported that APACHE II and SOFA scores at hospitalization were found to be associated with mortality in 21 patients with SADs who were followed up in the ICU due to diffuse alveolar hemorrhage, and $85 \%$ of the patients needed mechanical ventilation (11). In our study, 11 patients were admitted to the ICU due to diffuse alveolar hemorrhage; they had high mortality rates and greater need for IMV. In addition, our study found that the need for IMV was associated with ICU mortality. We believe that this may be due to severe hypoxia that is secondary to ventilatory associated pneumonia (VAP) or can otherwise be observed in these patients.

In a study conducted in France in which 31 patients with SADs treated in the ICU were evaluated over a 10-year period, APACHE II scores and SAPS II were found to be associated with mortality, whereas the Birmingham Vasculitis Activity Score (BVAS), which assesses the severity of vasculitis, appeared to be clinically related but could not be statistically correlated with mortality. In addition, the need for renal replacement therapy and catecholamines were also associated with mortality. Unlike our study's sex ratio, 21 patients in that study were male and 10 were female. Eighty-one percent of the patients needed mechanical ventilation, and $52 \%$ died in the ICU. The most common cause of death was found to be septic shock (2). In our study, APACHE II and SOFA scores were found to be associated with mortality, which was in line with the literature, but BVAS was not assessed as it was not actively used in our clinic; as a result, the correlation between disease activity and mortality could not be evaluated.

As per a review published in 2013 on patients with SADs requiring ICU admission, respiratory failure was the most common reason for ICU admission and, in addition to what was already reported in the literature, multiple organ failure and advanced age were found to be associated with mortality (5). In some studies, in addition to these criteria, infection as the reason for ICU admission, prolonged hospitalization before ICU admission, shock, use of vasopressors, and the need for mechanical ventilation and plasmapheresis were also associated with mortality $(12,13)$. The length of stay in the ICU and presence of renal and cardiovascular comorbidities during stay in the ICU are other risk factors associated with mortality (8).

In a prospective randomized study of 2020 that compared plasma exchange and glucocorticoid treatments in antineutrophil cytoplasmic antibody (ANCA)-associated vasculitis, it was found that plasmapheresis therapy did not contribute to standard treatment and low-dose glucocorticoid treatment was not inferior to high-dose treatment (14). These findings led us to think that using low-dose steroid treatments or adjusting the dose for patients in the ICU may be beneficial for them since these treatments may predispose them to infections during ICU stay although a direct relationship with mortality could not be established.

In a study that assessed 34 cases of ANCAassociated vasculitis treated for the first time in the internal medicine ICUs of 4 university hospitals of Turkey between 2008 and 2018, 20 patients $(58.8 \%)$ died during treatment in the ICU, with septic shock being the most common cause of death $(60 \%)$, followed by hemoptysis and respiratory failure $(20 \%)$ and hemorrhagic shock $(10 \%)$. There was no difference between the patients that died and the survivors in terms of the immunosuppressive therapy administered. Acinetobacter baumannii was found to be the most common cause of new-onset infections in patients who survived and those who died during their stay in the ICU. Consistent with the literature, in mentioned study, APACHE II and SOFA scores and SAPS II were found to be associated with mortality, but BVAS was not associated with ICU mortality. Researchers evaluating short-term mortality in this group of patients also concluded that new-onset ICU infections, shock, need for vasopressor, thrombocytopenia, need for platelet transfusion, and liver dysfunction were associated with mortality in this group 
(15). In our study, a statistically significant increase was found between mortality and the need for IMV. The mortality rate in patients who needed IMV was $70 \%$. No correlation was found between mortality and steroid treatments used during hospitalization and immunomodulatory treatments. However, it was observed that there was a significant relationship between the use of biological agents during treatment and increased mortality. Nevertheless, since we could not find a study evaluating the correlation between the use of biological agents and mortality, we could not make a comparison on this subject. In order to clarify this, we believe there is a need for evaluating whether the necessity of using biological agents in the treatment algorithm of the patients includes other concomitant factors that increase mortality. In light of these findings, we believe that limiting the use of biological agents or administering alternative treatments to patients admitted to the ICU can be considered.

In our study, the presence of fungal infection as per fungal cultures performed at the time of hospitalization was found to be associated with mortality. In addition, $48.83 \%$ (21/43) of the patients had a growth of gram-negative bacteria in the cultures, and $90 \%$ of these patients died. Furthermore, $80 \%$ patients with

\section{REFERENCES}

1. Heijnen $\mathrm{T}$, Wilmer A, Blockmans $\mathrm{D}$, et al. Outcome of patients with systemic diseases admitted to the medical intensive care unit of a tertiary referral hospital: a single-centre retrospective study. Scand J Rheumatol. 2015;1-5

2. Befort P, Corne P, Filleron T, et al. Prognosis and ICU outcome of systemic vasculitis. BMC Anesthesiology. 2013 13:27.

3. Janssen NM, Karnad DR, Guntupalli KK. Rheumatologic diseases in the intensive care unit: epidemiology, clinical approach, management, and outcome. Crit Care Clin. 2002;18:729-748.

4. Camargo JF, Tobón GJ, Fonseca N, et al. Autoimmune rheumatic diseases in the intensive care unit: experience from a tertiary referral hospital and review of the literature. Lupus. 2005;14:315-320.

5. Quintero OL, Rojas-Villarrage A, Mantilla RD, et al. Autoimmune diseases in the intensive care unit. An update. Autoimmun Rev. 2013;12:380-395. the presence of gram-positive bacteria and all patients with atypical bacterial growth died. In their study, Ozdemir et al. (15) found that new-onset ICU infections mostly caused by A. baumannii were associated with mortality. Similarly, our study showed that infections existing at the time of hospitalization were also associated with mortality. Therefore, due to these reasons and owing to the predisposition of this patient group to infections by gram-negative bacteria and fungi, we believe it would be appropriate to maintain the use of empirical broad-spectrum anti-infective agents.

\section{Conclusion}

In our study, the main limitation of which was its retrospective design, we observed that SADs requiring ICU admission included SLE and systemic vasculitis; this finding was in line with the literature. In addition, we found that bacterial and fungal infections and sepsis caused by immunosuppression due to the drugs used in the treatment of these diseases were the leading reasons for ICU admission. Therefore, we conclude that raising the awareness of such patients regarding infections and sepsis, which are preventable causes, and implementation of specific measures in this area could reduce the cases of ICU admissions in this patient group and may be effective in reducing deaths.
6. Cimmino MA, Massocco M, Torre M. Hospital admission for rheumatoid arthritis dwindled in Italy between 2001 and 2008. Rheumatology (Oxford). 2011;50:2140-2141. 21.

7. Wludarczyk A, Polok K, Gorka J, et al. Patients with small-vessel vasculitides have the highest mortality among systemic autoimmune diseases patients treated in intensive care unit: A retrospective study with 5-year follow-up. Crit Care. 2018 ;48:166-171.

8. Parparis K, Al-Charakh M, Nzuonkwelle S, et al. Characteristics and Outcomes Among Patients With Autoimmune Rheumatic Diseases Requiring a Higher Level of Care. J Clin Rheumatol. 2021 ;27:286-291.

9. Anton JM, Castro P, Espinosa G, et al. Mortality and long term survival prognostic factors of patients with systemic autoimmune diseases admitted to an intensive care unit: a retrospective study. Clin Exp Rheumatol.2012; 30:338-344. 
10. Heijnen T, Wilmer A, Blockmans D, et al. Outcome ofpatients with systemic diseases admitted to the medical intensive care unit of a tertiary referral hospital: a single-centre retrospective study. Scand JRheumatol. 2016;45:146-150. 22.

11. Polok K, Włudarczyk A, Szczeklik W. Clinical profile of patients with systemic autoimmune diseases treated in the intensive care unit who developed diffuse alveolar haemorrhage - an observational retrospective cohort study. Anaesthesiol Intensive Ther. 2019;51:96-101.

12. Moreels M, Mélot C, Leeman M. Prognosis of patients with systemic rheumatic diseases admitted to the intensive care unit. Intensive Care Med. 2005;31:591-3.

13. Bernal-Macias S, Reyes-Beltran B, MolanoGonzalez N, et al. Outcome of patients with autoimmune diseases in the intensive care unit: a mixed cluster analysis. Lupus Sci Med. 2015;2:e000122.

14. Walsch M, Merkel PA, Peh CA, et al. Plasma Exchange and Glucocorticoids in Severe ANCAAssociated Vasculitis. $N$ Engl $J$ Med. 2020;382:622-31.

15. Özdemir U, Ortaç Ersoy E, Yüksel RC, et al. Value of prognostic scores in antineutrophil cytoplasmic antibodies (ANCA) associated vasculitis patients in intensive care unit: a multicenter retrospective cohort study from Turkey. Turk J Med Sci. 2020; 50: 1223-30 